\title{
Co-infection with Influenza A and COVID-19
}

\author{
Venu Madhav Konala ${ }^{1}$, Sreedhar Adapa², Vijay Gayam³ ${ }^{3}$ Srikanth Naramala, Subba Rao Daggubati ${ }^{5}$, \\ Chetan Brahma Kammari ${ }^{6}$, Avantika Chenna ${ }^{7}$ \\ ${ }^{1}$ Department of Internal Medicine, Division of Medical Oncology, Ashland Bellefonte Cancer Center, Ashland, KY, USA \\ ${ }^{2}$ Department of Internal Medicine, Division of Nephrology, Adventist Medical Center, Hanford, CA, USA \\ ${ }^{3}$ Department of Medicine, Interfaith Medical Center, Brooklyn, NY, USA \\ ${ }^{4}$ Department of Internal Medicine, Division of Rheumatology, Adventist Medical Center, Hanford, CA, USA \\ ${ }^{5}$ Wise Health System, Decatur, TX, USA \\ ${ }^{6}$ Internal Medicine, Cape Fear Valley Hospital, Fayetteville, NC, USA \\ ${ }^{7}$ Phobe Putney Memorial Hospital, Medical College of Georgia, Albany, GA, USA6
}

\section{Doi: 10.12890/2020_001656 - European Journal of Case Reports in Internal Medicine - @ EFIM 2020}

Received: 12/04/2020

Accepted: $17 / 04 / 2020$

Published: 20/04/2020

How to cite this article: Konala VM, Adapa S, Gayam V, Naramala S, Duggubati SR, Kammari CB, Chenna A. Co-infection with influenza A and COVID-19. EJCRIM 2020;7: doi:10.12890/2020_001656.

Conflicts of Interests: The Authors declare that there are no competing interests.

This article is licensed under a Commons Attribution Non-Commercial 4.0 License

\section{ABSTRACT}

COVID-19, also called severe acute respiratory distress syndrome coronavirus 2 (SARS-CoV-2), originated in Wuhan, China. It has caused significant morbidity and mortality worldwide and has been declared a global pandemic by the WHO. Influenza occurs mainly during the winter, with the burden of disease determined by several factors, including the effectiveness of the vaccine that season, the characteristics of the circulating viruses, and how long the season lasts. We describe the case of a 66-year-old woman who was diagnosed with influenza A and COVID-19 co-infection.

\section{LEARNING POINTS}

- COVID-19 can co-occur with other viral infections.

- Some of these co-infections have active treatments, while supportive treatment is the mainstay of treatment for others.

\section{KEYWORDS}

Coronavirus, COVID-19, influenza, acute respiratory distress syndrome

\section{INTRODUCTION}

COVID-19, also called severe acute respiratory distress syndrome coronavirus 2 (SARS-CoV-2), originated in Wuhan, China. It has caused significant morbidity and mortality worldwide and has been declared a global pandemic by the WHO ${ }^{[1]}$. The USA currently has the highest number of positive cases and the highest number of deaths globally as the disease continues to spread across the country ${ }^{[2]}$. We describe the case of a 66-year-old woman with a diagnosis of influenza A and COVID-19 co-infection.

\section{CASE DESCRIPTION}

A 66-year-old African-American woman was referred by her primary care provider with a syncopal episode. She complained of fever with a maximum temperature of $38.9^{\circ} \mathrm{C}$ as well as a non-productive cough, shortness of breath and decreased appetite 3 days before presentation. Her medical history was significant for ischaemic cardiomyopathy, type 2 diabetes mellitus, hypertension, coronary artery disease, and chronic kidney disease with a baseline creatinine of 1.3. Her surgical history was significant for right carotid endarterectomy in 2018 and placement of an automated internal cardioverter defibrillator in 2012. Patient characteristics are summarized in Table 1. 
Her vital signs on presentation were blood pressure of 140/70 mmHg, heart rate of $81 \mathrm{bpm}$, respiratory rate of $19 \mathrm{bpm}$, temperature of $37.8^{\circ} \mathrm{C}$, and an oxygen saturation of $91 \%$ on a nasal cannula with a flow rate of $2 \mathrm{l} / \mathrm{min}$. Physical examination was significant for obesity but no acute distress, and coarse breath sounds bilaterally on auscultation. The rest of the examination was unremarkable.

The patient's laboratory test results are given in Table 2. The influenza A test was positive. The nasopharyngeal swab was sent for COVID-19 testing, which was reported positive a couple of days later. A chest x-ray showed a right lower lobe infiltrate (Fig. 1).

\begin{tabular}{|l|l|}
\hline Characteristics & Patient information \\
\hline Symptoms & Cough, shortness of breath, fever \\
\hline Smoking & Ex-smoker, quit in 2004 \\
\hline Co-morbidities & $\begin{array}{l}\text { Hypertension } \\
\text { Diabetes } \\
\text { Chronic kidney disease stage 3 } \\
\text { Congestive heart failure } \\
\text { Coronary artery disease }\end{array}$ \\
\hline $\begin{array}{l}\text { Patient on ACE inhibitors or } \\
\text { angiotensin receptor blockers }\end{array}$ & Losartan 25 mg \\
\hline Diuretics & Patient not on any diuretics \\
\hline $\begin{array}{l}\text { Non-steroidal anti-inflammatory } \\
\text { drugs (NSAIDs) }\end{array}$ & Patient not on any NSAIDs \\
\hline
\end{tabular}

\begin{tabular}{|l|l|}
\hline Laboratory parameter & Patient values \\
\hline Haemoglobin & $13.8 \mathrm{~g} / \mathrm{dl}$ \\
\hline White cell count & $6,100 / \mathrm{mm} 3$ \\
\hline Lymphocyte count & $1,000 / \mathrm{mm} 3$ \\
\hline Platelet count & $180 \mathrm{~K} / \mathrm{mm} 3$ \\
\hline Sodium & $140 \mathrm{mmol} / \mathrm{l}$ \\
\hline Potassium & $4.3 \mathrm{mmol} / \mathrm{l}$ \\
\hline Bicarbonate & $28 \mathrm{mmol} / \mathrm{l}$ \\
\hline Blood urea nitrogen & $26 \mathrm{mg} / \mathrm{dl}$ \\
\hline Serum creatinine & $1.56 \mathrm{mg} / \mathrm{dl}$ \\
\hline Creatinine phosphokinase & $89 \mathrm{U} / \mathrm{l}$ \\
\hline Urine analysis & $\begin{array}{l}\text { No protein } \\
\text { No RBC casts }\end{array}$ \\
\hline Urine protein creatinine ratio & $100 / 74$ \\
\hline Influenza A & Positive \\
\hline COVID-19 & Positive \\
\hline & \\
\hline
\end{tabular}


The patient was initially admitted to the medical department and was started on Tamiflu $30 \mathrm{mg}$ by mouth twice a day for 5 days, along with azithromycin and ceftriaxone for treatment of community-acquired pneumonia, and hydroxychloroquine for suspected COVID-19 as per hospital protocol. The patient was started on intravenous (IV) normal saline for acute kidney injury with improvement in renal function. However, the patient's clinical condition deteriorated with hypoxia despite the use of high-flow oxygen and she was transferred to the intensive care unit when the initial $\mathrm{ABG}$ showed a pH of 7.3, $\mathrm{PO}_{2}$ of $59 \mathrm{mmHg}$ and $\mathrm{PCO}_{2}$ of $45 \mathrm{mmHg}$ despite the fact that she was on highflow oxygen via a nasal cannula at $40 \mathrm{l} / \mathrm{min}$.

Subsequently, the patient was intubated and ventilated. Her losartan was stopped, while IV fluids were continued. However, renal deterioration progressed so IV fluids were also discontinued and the patient was started on diuretics. Nevertheless, renal failure continued to worsen and as the patient was found to be dehydrated, diuretics were stopped. Urine output subsequently increased, and the creatinine improved to 1.5, closer to the patient's baseline value. The patient continues to be ventilator-dependent with minimal settings with an Fio2 of $30 \%$ with a plan for tracheostomy and percutaneous gastrostomy tube placement.

\section{DISCUSSION}

COVID-19 can initially present with minor symptoms such as fever with or without chills, dry cough, shortness of breath, fatigue, muscle aches, sore throat, confusion, headache and rhinorrhoea. The lung is the main organ affected, which can result in respiratory failure. The disease can also present with atypical symptoms such as nausea, vomiting and diarrhoea ${ }^{[1]}$.

Influenza in the USA occurs mainly during winter, and the burden of disease is determined by several factors, including the effectiveness of the vaccine that season, the characteristics of the circulating viruses, and how long the season lasts. According to CDC estimates, during the 2018-2019 season symptomatic influenza occurred in approximately 35 million patients, which resulted in approximately 16 million hospital visits and approximately 500,000 hospitalizations with 34,000 deaths ${ }^{[3]}$. The most common symptoms of influenza are fever, cough, shortness of breath, fatigue, headache, myalgia and arthralgia, similar to those of COVID-19.

COVID-19 can simultaneously present with other infections such as influenza, and it can be hard to distinguish the symptoms of the two conditions from each other. However, there are differences and these are summarized in Table $3^{[1]}$. A study by Xing et al. analysed common respiratory pathogens presenting as co-infections with COVID-19 from Quingdao and Wuhan. This report identified IgM antibodies to at least one respiratory pathogen in $80 \%$ and $2.6 \%$ of the patients from Quingdao and Wuhan, respectively. Influenza A, influenza B, followed by Mycoplasma and Legionella, were the most common respiratory pathogens detected ${ }^{[4]}$.

\begin{tabular}{|c|c|c|}
\hline & Influenza & COVID-19 \\
\hline Asymptomatic or symptomatic & $\begin{array}{c}\text { Patients can be asymptomatic } \\
\text { due to herd immunity }\end{array}$ & $\begin{array}{l}\text { Most patients develop } \\
\text { symptoms within } 2 \text { days } \\
\text { of infection }\end{array}$ \\
\hline Viral shedding & $5-10$ days & $\begin{array}{l}\text { Up to } 14 \text { days or even } \\
\text { longer }\end{array}$ \\
\hline Severity of illness & $\begin{array}{l}\text { Majority of infections are } \\
\text { mild to moderate }\end{array}$ & Severe illness can occur \\
\hline Mortality & Less than $1 \%$ & $3-4 \%$ \\
\hline Vaccines & $\begin{array}{l}\text { Vaccines available; } \\
\text { efficacy varies from } \\
\text { season to season }\end{array}$ & $\begin{array}{l}\text { No vaccine available, } \\
\text { clinical trials in progress }\end{array}$ \\
\hline Treatment & $\begin{array}{l}\text { Oseltamivir } \\
\text { Zanamivir } \\
\text { Peramivir } \\
\text { Baloxavir }\end{array}$ & $\begin{array}{l}\text { No treatment available, } \\
\text { clinical trials in progress }\end{array}$ \\
\hline $\begin{array}{l}\text { Acute respiratory distress } \\
\text { syndrome }\end{array}$ & Less common & More common \\
\hline
\end{tabular}

Table 3. Differences between influenza and COVID-19

In a study from Wuhan, five of 115 patients were co-infected with COVID-19 and influenza.

Most of these patients presented with fever, cough and shortness of breath. All of the co-infected patients presented with pharyngeal pain. Only one of the co-infected patients developed acute respiratory distress syndrome and required non-invasive ventilation. 
Acute liver injury occurred in three of the patients and diarrhoea in two. All patients were treated with oseltamivir, antibiotics and supplemental oxygen, and three of the patients required steroids ${ }^{[5]}$.

Many novel treatments for COVID-19 are under investigation, and although some of these options are already being used in clinical practice (as in our patient), none are currently approved for routine use. Many centres have started incorporating treatment with hydroxychloroquine and azithromycin based on a small study by Gautret et al., where the combination decreased the duration of viral shedding and increased elimination of the virus ${ }^{[6]}$.

We currently do not know the impact on patients of co-infection with both influenza and COVID-19, or whether influenza alters clinical outcomes in patients already infected with COVID-19.

\section{CONCLUSION}

Influenza and COVID-19 co-infection can occur in patients and can present with similar symptoms. It is essential to recognize the coinfections as some can be treated with antibiotics and antivirals. We already have treatments for influenza, but while multiple drugs are being investigated for COVID-19, none have been approved for treatment so far. We encourage patients to be vaccinated against pathogens causing respiratory infections to reduce the risk of co-infection.

\section{REFERENCES}

1. Balla M, Merugu GP, Patel M, Koduri NM, Gayam V, Adapa S, et al. COVID-19, modern pandemic: a systematic review from a front-line health care providers' perspective. J Clin Med Res 2020;12(4):215-229.

2. John Hopkins University of Medicine Coronavirus Resource Center. Available from https://coronavirus.jhu.edu/map.html (accessed 11 April 2020).

3. Centers for Disease Control and Prevention. Influenza (Flu). Available from https://www.cdc.gov/flu/about/burden/index.html (accessed 11 April 2020).

4. Xing Q, Li GJ, Xing YH, Chen T, Li WJ, Ni W, et al. Precautions are needed for COVID-19 patients with coinfection of common respiratory pathogens. Available from http://dx.doi. org/10.2139/ssrn.3550013 (accessed 17 April 2020).

5. Ding Q, Lu P, Fan Y, Xia Y, Liu M. The clinical characteristics of pneumonia patients co-infected with 2019 novel coronavirus and influenza virus in Wuhan, China. J Med Virol 2020 Mar 20. doi: 10.1002/jmv.25781 [Epub ahead of print].

6. Gautret P, Lagier JC, Parola P, Meddeb L, Mailhe M, Doudier B, et al. Hydroxychloroquine and azithromycin as a treatment of COVID-19: results of an open-label nonrandomized clinical trial. Int J Antimicrob Agents 2020 Mar 20:105949. doi: 10.1016/j.ijantimicag.2020.105949 [Epub ahead of print]. 